\title{
THE ASSOCIATION BETWEEN INDOOR HOUSEHOLD POLUTION AND ACUTE RESPIRATORY INFECTION IN CHILDREN UNDER FIVE IN SELAT COMMUNITY HEALTH CENTER, BATANGHARI DISTRICT, JAMBI, INDONESIA
}

\author{
Nanda Agustian Simatupang 1,2), Laras Ayu Wulandari1) \\ 1)Faculty of Public Health, Universitas Jambi \\ ${ }^{2)}$ Masters Program in Public Heath, Universitas Sebelas Maret
}

\begin{abstract}
Background: Acute respiratory tract infections constitute the major causes of mortality and morbidity of the developing world. The risk factors of acute respiratory tract infections have been identified such as passive smoking, the practice of burning mosquito coils indoors, and firewood for cooking. The purpose of this study was examine

Subjects and Method: A case control study was carried out at Selat community health center, Batanghari district, Jambi, Indonesia, from May to July 2020. A sample of 132 children under five aged 12-59 months was selected by purposive sampling. The dependent variable was acute respiratory infection. The independent variables were smoking behavior of family member, repellant coil use, and firewood use. The data were collected by questionnaire, medial record, and observation sheet. The data were analyzed by Chi square. Results: Acute respiratory infection in children under five increased with family member smoking behavior $(\mathrm{OR}=4.73 ; 95 \% \mathrm{CI}=2.20$ to $10.17 ; \mathrm{p}<0.001)$, mosquito coils $(\mathrm{OR}=1.26$; $95 \% \mathrm{CI}=0.48$ to $3.29 ; \mathrm{p}=0.627)$, and firewood use for cooking $(\mathrm{OR}=1.28 ; 95 \% \mathrm{CI}=0.57$ to $2.89 ; \mathrm{p}=0.538)$.

Conclusion: Acute respiratory infection in children under five increased with family member smoking behavior, mosquito coils, and firewood use for cooking.
\end{abstract}

Keywords: acute respiratory infection, smoking, children under five

\section{Correspondence:}

Nanda Agustian Simatupang. Masters Program in Public Health, Universitas Sebelas Maret. Jl. Ir. Sutami 36A, Surakarta 57126, Central Java. Email: nandaagustians9@gmail.com. Mobile: +6282247604322. 